\title{
EFFECT OF SOME HERBICIDES APPLICATION ON NITRATES (V) CONTENT IN POTATO TUBERS
}

\author{
Krystyna Zarzecka', Marek Gugała', Honorata Dołęga', Iwona Mystkowska², \\ Alicja Baranowska², Anna Sikorska', Bożena Głuszczak' \\ 1 Department of Agrotechnology, Faculty of Natural Science, Siedlce University of Natural Sciences and \\ Humanities, Prusa St. 14, 08-110 Siedlce, Poland, e-mail: kzarzecka@uph.edu.pl, gugala@uph.edu.pl \\ 2 Department of Environment Sciences, Pope John Paul II State School of Higher Education, Sidorska St. 95/97, \\ 21-500 Biala Podlaska, Poland
}

Received: 2016.03.07

Accepted: 2016.06.01 Published: 2016.07.01

\begin{abstract}
A field experiment was carried out in the Agricultural Experimental Station Zawady ( $52^{\circ} 03^{\prime}$ N; $22^{\circ} 33^{\prime} \mathrm{E}$ ), owned by the Siedlce University of Natural Sciences and Humanities in 2005-2007. The research was designed as a two factors randomized block with three replicates. The factors examined in the experiment included two potato varieties - Irga and Balbina and four weed control methods combined mechanical and chemical for herbicides application: Plateen 41,5 WG (metribuzin + flufenacet), Racer 250 EC (fluorochloridone), Sencor 70 WG (metribuzin), and control object mechanical weeding before and after potato sprouting. The study was designed to test the influence of weed control methods on nitrates content in consumption potato tubers. The nitrates $(\mathrm{V})$ content depended on the weed control methods, varieties and weather conditions throughout the growing season. The highest nitrates (V) content was determined when weeds were controlled mechanically and chemically using Sencor $70 \mathrm{WG}$. The study results demonstrated that Balbina had a higher concentration of nitrates (V) compared with Irga.
\end{abstract}

Keywords: herbicides, nitrates (V), potato tubers, varieties

\section{INTRODUCTION}

Potato is an important staple food in Poland as in many other countries [Camire et al. 2009, Horvat et al. 2014, Leszczyński 2012, Ezekiel et al. 2013, Wegener et al. 2015]. The annual average per capita consumption of potatoes in Poland over the past few years is about 112-130 $\mathrm{kg}$ per year [Dzwonkowski et al. 2012]. The quality of potato tubers depends on chemical composition, which can significantly affect the nutrient availability of the potato. Potato tubers contain nutritional components and also anti-nutritional ingredients such as nitrates, glycoalkaloids, heavy metals and pesticides [Kolasa 1993, Rembiałkowska, Średnicka 2009, Wierzbicka 2011]. The smallest possible content of these toxins in potato tubers is required.
Potato, as other plants, have a medium inclination to nitrates accumulation in potato tubers [Grudzińska, Zgórska 2008]. The nitrates amount is required to be less than $200 \mathrm{mg} \mathrm{kg}^{-1}$ on a fresh weight basis [Directive 2005]. These compounds are harmful to health, when under the influence of the oral cavity enzymes and intestinal bacteria in the downstream sections of the gastrointestinal tract will be reduced to nitrites. Besides the oxidation of hemoglobin to methemoglobin, which is unable to carry oxygen, they can cause also lower blood pressure. Furthermore, nitrates affect destruction of vitamin A, vitamin B and carotenoids, it also may have carcinogenic and mutagenesis action [Camire et al. 2009, Gajewska et al. 2009, Marks 2009]. Nitrates (V) accumulation in potato tubers is affected by many factors: cultivar properties [Frydecka-Mazurczyk, Zgórska 
2000, Lachman et al. 2005, Gugała, Zarzecka 2009], agronomical factors which primarily are: fertilization, tillage, protection against agrophages [Frydecka-Mazurczyk, Zgórska 1996, Lachman et al. 2005, Zarzecka et al. 2010, Wierzbicka 2011], environmental conditions [Rogozińska et al., 2005, Grudzińska, Zgórska 2008, Bensa et al. 2012]. The aim of this study was to determine the impact of the reducing weeds herbicides on nitrates $(\mathrm{V})$ content in the tubers of two potato varieties.

\section{MATERIALS AND METHODS}

The results of the study derive from the field experiment carried in the Agricultural Experimental Station Zawady (52 $03^{\prime} \mathrm{N}$; $\left.22^{\circ} 33^{\prime} \mathrm{E}\right)$, owned by the Siedlce University of Natural Sciences and Humanities in Poland. The field experiment was performed in the years 2005-2007 on sandy soil, IVa class, with $\mathrm{pH}$ being slightly acidic and acidic. The soil was characterized by the mean to very high content of phosphorus and potassium, moreover by the magnesium content ranging from high to very high (Table 1). The research was designed in a split-plot system in three replications, including two different factors. Factor I included two edible potato varieties: Irga and Balbina, and factor II: four methods of weed control:

1) mechanical weed control in the period prior to potato emergence and after potato emergence control object,

2) combined mechanical and chemical weed control, including ridging and harrowing and ridging and treatment with herbicide Plateen 41,4 WG (metribuzin + flufenacet) at a dose of $2.0 \mathrm{~kg} \cdot \mathrm{ha}^{-1}$ immediately before the emergence of potato plants,

3) combined mechanical and chemical weed control, comprising single ridging and treatment with herbicide Racer 250 EC (fluorochloridone) applied at a dose of $3.01 \cdot \mathrm{ha}^{-1}$ up to 10 days after planting potato tubers,

4) combined mechanical and chemical weed control, including ridging and harrowing and ridging, and treatment with herbicide Sencor $70 \mathrm{WG}$ (metribuzin), dosed $1.0 \mathrm{~kg} \cdot \mathrm{ha}^{-1}$, immediately before the potato emergence.

Potato was cultivated in the field after winter triticale. In autumn the farmyard manure in amount of $25.0 \mathrm{t} \cdot \mathrm{ha}^{-1}$ as an organic fertilizer, and mineral fertilizations were applied at the re- spective rates of $39.6 \mathrm{~kg} \mathrm{P}$ (in the form of $46 \%$ triple superphosphate), $112.1 \mathrm{~kg} \mathrm{~K}$ (in the form of $60 \%$ potassium salt) per 1 ha. In springtime before planting time, the nitrogen fertilizers were applied in the dose $\mathrm{N}-90 \mathrm{~kg} \cdot \mathrm{ha}^{-1}$ (in the form of $34 \%$ ammonium saltpeter). Potatoes were planted in the third decade of April and were harvested at proper stage of maturity in the third decade of September and in the first decade of October. Nitrates $(\mathrm{V})$ content was determined with ionoselective nitrate electrode and chlorinesilver reference electrode [Kolbe, Müller 1987]. The results were subjected to the statistical analysis with the method of the analysis of variance. Significance of variability sources was tested with the FisherSnedecor ' $F$ ' test, and rating significance of differences at $\mathrm{P}=0.05$ between the compared means using Tuke'y test.

The weather conditions in the years of the research period was varied (Table 2). In growing season in 2005 the rainfall was lower by 74.5 $\mathrm{mm}$ than in multiyear period. June 2006 was less wet with higher air temperature, moreover during the growing season, rainfalls were unevenly distributed, air temperatures were higher than in multi-year period 1981-1995. In 2007 the rainfall was the most abundant additionally it was the warmest year. In 2007 the growing season was characterized by the most favorable climate conditions - rainfalls were evenly distributed and air temperatures were virtually the same as in the multiyear period.

\section{RESULTS AND DISCUSSION}

The research studies gave result of $110.68 \mathrm{mg}$ $\mathrm{kg}^{-1}$ of nitrates $(\mathrm{V})$ content in fresh matter of potato tubers, which was close to the data obtained by other authors [Frydecka-Mazurczyk, Zgórska 2000, Lachman et al. 2005, Zarzecka et al. 2010, Abbasi et al. 2011], furthermore the amount was twice lower than permitted by the Directive [Directive 2005].

Herbicides used in the research for weed control (Plateen 41,5 WG, Racer 250 EC, Sencor $70 \mathrm{WG}$ ) significantly increased the concentration of nitrates $(\mathrm{V})$ in potato tubers in comparison with control object (Table 3). Hamouz et al. [2005], Lachman et al. [2005] observed an increased nitrates content in tubers in the conventional tillage method with herbicides application comparing with the tubers of the eco- 
Table 1. Chemical properties of the soil in experiment

\begin{tabular}{|c|c|c|c|c|c|}
\hline \multirow{2}{*}{ Years } & $\begin{array}{c}\mathrm{pH} \\
1 \mathrm{~mol}\end{array}$ & \multicolumn{3}{|c|}{ Macroelements content $\left(\mathrm{mg} \mathrm{kg}^{-1}\right)$} \\
\cline { 3 - 6 } & $\mathrm{KCl}^{-3}$ & $\mathrm{~N}$ total & $\mathrm{P}$ & $\mathrm{K}$ & $\mathrm{Mg}$ \\
\hline 2005 & 5.74 & 0.91 & 43.0 & 85.7 & 145.2 \\
2006 & 5.50 & 0.68 & 55.0 & 180.0 & 50.0 \\
2007 & 4.99 & 0.88 & 99.4 & 149.4 & 51.0 \\
\hline
\end{tabular}

Table 2. Weather conditions in potato growing season in the years 2005-2007

\begin{tabular}{|c|c|c|c|c|c|c|c|}
\hline \multirow{2}{*}{ Years } & \multicolumn{7}{|c|}{ Months } \\
\hline & IV & V & $\mathrm{VI}$ & VII & VIII & IX & IV-IX \\
\hline \multicolumn{8}{|c|}{ Rainfalls (mm) } \\
\hline 2005 & 12,3 & 64,7 & 44,1 & 86,5 & 45,4 & 15,8 & 268,8 \\
\hline 2006 & 29,8 & 39,6 & 24,0 & 16,2 & 228,1 & 20,9 & 358,6 \\
\hline 2007 & 21,2 & 59,1 & 59,0 & 70,2 & 31,1 & 67,6 & 308,2 \\
\hline $\begin{array}{c}\text { Mean sum in multiyear } \\
(1981-1995)\end{array}$ & 52,3 & 50,0 & 68,2 & 45,7 & 66,8 & 60,7 & 343,7 \\
\hline \multicolumn{8}{|c|}{ Air temperature $\left({ }^{\circ} \mathrm{C}\right)$} \\
\hline 2005 & 8,7 & 13,0 & 15,9 & 20,2 & 17,5 & 15,0 & 15,0 \\
\hline 2006 & 8,4 & 13,6 & 17,2 & 22,3 & 18,0 & 15,4 & 15,8 \\
\hline 2007 & 8,6 & 14,6 & 18,2 & 18,9 & 19,9 & 13,1 & 15,4 \\
\hline $\begin{array}{l}\text { Mean for multiyear } \\
(1981-1995)\end{array}$ & 7,7 & 10,0 & 16,1 & 19,3 & 18,0 & 13,0 & 14,0 \\
\hline
\end{tabular}

Table 3. Content of nitrates $(\mathrm{V})$ in potato tubers $\left(\mathrm{mg} \mathrm{kg}^{-1}\right.$ fresh matter)

\begin{tabular}{|l|c|c|c|c|c|c|}
\hline \multirow{2}{*}{ Weed control methods } & \multicolumn{2}{c|}{ Varieties } & \multicolumn{3}{c|}{ Years } & \multirow{2}{*}{ Mean } \\
\cline { 2 - 7 } & Irga & Balbina & 2005 & 2006 & 2007 & 109.95 \\
\hline 1. Control object & 102.72 & 117.25 & 109.60 & 115.79 & 104.58 & 111.04 \\
2. Plateen 41,5 WG & 104.09 & 117.99 & 110.47 & 116.52 & 106.13 & 110.63 \\
3. Racer 250 EC & 103.69 & 117.56 & 110.07 & 116.34 & 105.47 & 111.11 \\
4. Sencor 70 WG & 104.12 & 118.09 & 110.70 & 116.60 & 106.02 & 110.68 \\
\hline Mean & 103.66 & 117.72 & 110.21 & 116.31 & 105.55 & \\
\hline LSD & & & & \\
for: years $=0.42$, varieties $=0.27$, weed control methods $=0.36$ \\
interaction: weed control methods $x$ years = n.s.
\end{tabular}

n.s. - no significant difference

logical tillage method. Although the differences were not statistically confirmed. Zarzecka et al. [2010] also did not show the influence of herbicides on nitrates $(\mathrm{V})$ content in tubers, but they reported a tendency to increase. Chemical weed control allow to obtain high yields of the desired quality, and pesticides used at optimal doses and terms should not affect the health of the consumer or biological quality of the plants and the soil [Baćmaga et al. 2007].

The conducted studies revealed different nitrates (V) amounts in tubers of potato varieties. Significantly higher amount was accumulated by Balbina variety than Irga. The differences between cultivars in respect to nitrate accumulation are indicated in studies of many authors [Frydecka-Mazurczyk, Zgórska, 2000, Lachman et al. 2005, Gugała, Zarzecka 2009, Marks 2009]. Frydecka-Mazurczyk, Zgórska [1996] and Wierzbicka [2011] demonstrate that main crop and late main crop have lower nitrates accumulation than early varieties.

The tubers harvested in individual years of this research differed in nitrates $(\mathrm{V})$ content (Table 3, 4). Comparing to previous years, the highest amount of nitrates was accumulated in potato tubers in 2006, the warmest and exceptionally wet year. Furthermore, it was characterized by unevenly distributed rainfall over the months of growing time. Nevertheless the smallest amount of these compounds was found in potato tubers harvested in 2007 with evenly distributed rainfall, whereas temperature was pretty near the average sum for the multiyear period. As 
Table 4. Content of nitrates (V) in potato tubers depending on the varieties ( $\mathrm{mg} \mathrm{kg}^{-1}$ fresh matter)

\begin{tabular}{|c|c|c|c|}
\hline \multirow{2}{*}{ Years } & Irga & Balbina & \multirow{2}{*}{ Mean } \\
\cline { 2 - 4 } & 102.50 & 117.91 & 110.21 \\
\hline 2005 & 108.97 & 123.65 & 116.31 \\
2006 & 99.50 & 111.60 & 105.55 \\
2007 & 103.66 & 117.72 & 110.68 \\
\hline Mean & \multicolumn{2}{|}{} \\
\hline
\end{tabular}

stated by: Frydecka-Mazurczyk, Zgórska [2000], Gugała, Zarzecka [2009] the least content of nitrates in tubers was determined by the average air temperature $\left(16-18{ }^{\circ} \mathrm{C}\right)$ and optimal total rainfall during the growing season. Grudzińska, Zgórska [2008] and Pobereżny [2008] were observing increase of nitrates level during severe weather conditions in growing season (low or high level of rainfall, either too high temperature or temporary rain shortage).

The nitrates (V) found in the tubers do not pose a threat to human health if the potato is grown in optimal wheather and soil conditions, and agricultural practices are carried out properly and in accordance with the direction of use. Although, the occurrence of these compounds is reduced approximately $35-36 \%$ by peeling potatoes for traditional potato consumption [Gołaszewska, Zalewski 2001, Zarzecka et al. 2010]. Mozolewski and Smoczyński 2004] showed that after preliminary process (washing, manual peeling and rinsing) that nitrates amount was reduced from 25.5 to $75.3 \%$ and it depended on potato variety.

\section{CONCLUSIONS}

The study results have demonstrated that nitrates (V) content depended on the weed control methods, varieties and weather conditions throughout the growing season. The highest nitrates $(\mathrm{V})$ content was determined when weeds were controlled mechanically and chemically using herbicide Sencor 70 WG. The variety Balbina had a higher concentration of nitrates $(\mathrm{V})$, on average $117.72 \mathrm{mg} \cdot \mathrm{kg}^{-1}$ fresh matter, compared with Irga $-103.66 \mathrm{mg} \cdot \mathrm{kg}^{-1}$. The highest concentration of nitrates $(\mathrm{V})$ in potato tubers was obtained in 2006, which was warmest and exceptionally wet year for potato growth.

\section{REFERENCES}

1. Abbasi A., Mahomoodabad RZ., Somarin S.J. 2011. Study of nitrogen fertilizer effect on agronomic nitrogen use efficiency, yield and nitrate accumulation in potato tubers cultivars in Ardabil Region (Iran). Advances in Environmental Biology, 5(4), 566-572.

2. Baćmaga M., Kucharski J., Wyszkowska J. 2007. Impact of crop protection chemicals on plants and animals. Journal of Elementology, 12 (2), 135-148.

3. Bensa A., Rubinic V., Sever-Strukil Z. 2012. The effect of nitrogen fertilization on nitrate leaching under potato production. Third International Scientific Symposium ”Agrosym Jahorina 2012", 368-372.

4. Camire ME. Kubow S., Donnelly DJ. 2009. Potatoes and human health. Critical Reviews in Food Science and Nutrition, 49(10), 823-840. doi: 10.1080/10408390903041996

5. Directive Komisji (WE) nr 1822/2005 z dnia 8 listopada 2005 r. zmieniające rozporządzenie (WE) nr 466/2001 w odniesieniu do azotanów w niektórych warzywach (Tekst mający znaczenie dla EOG).

6. Dzwonkowski W., Szczepaniak I., Zdziarska T., Mieczkowski M. 2012. Potato's market. State and perspectives. Wyd. IERiGŻ-PIB, ARR, MRiRW, Warszawa, 39, 12-19.

7. Ezekiel R., Singh N., Sharma S., Kaur, A. 2013. Beneficial phytochemicals in potato - a review. Food Research International, 50, 487-496. doi: 10.1016/j.foodres.2011.04.025

8. Frydecka-Mazurczyk A., Zgórska K. 1996. Factors which affect content of nitrates in potato tubers. Biuletyn Instytutu Ziemniaka, 47, 111-125.

9. Frydecka-Mazurczyk A., Zgórska K. 2000. Content of nitrates in potato tubers dependent on genotype, place of cultivation and harvest date. Żywność Nauka Technologia Jakość, 4 (25) Supl., 46-52.

10. Gajewska M., Czajkowska A., Bartodziejska B. 2009. The content of nitrates (III) and (V) in selected vegetables on detail sale in Lodz region. Ochrona Środowiska i Zasobów Naturalnych, 40, 388-395. 
11. Gołaszewska B., Zalewski S. 2001. Optimisation of potato quality in the culinary process. Polish Journal of Food and Nutrition Sciences, 10(15), 59-63.

12. Grudzińska M., Zgórska K. 2008. Impact of weather conditions on the content of nitrates $(\mathrm{V})$ in potato tubers. Żywność Nauka Technologia Jakość, 5(60), 98-106.

13. Gugała M., Zarzecka K. 2009. Content of nitrates (V) in potato tubers in conditions of application of new generation insecticides. Ecological Chemistry and Engineering, A, 16(8), 927-931.

14. Hamouz K., Lachman J., Dvořak P., Pivec V. 2005. The effect of ecological growing on the potatoes yield and quality. Plant Soil and Environment, 51(9), 397-402.

15. Horvat T., Poljak M., Lazarevic B., Svečnjak Z., Hanaček K., 2014. Effect of foliar fertilizers on physiological characteristics of potato. Romanian Agricultural Research, 31, 159-165. doi: 20675720 RAR 2014-288

16. Kolasa KM. 1993. The potato and human nutrition. American Potato Journal, 70, 375-384.

17. Kolbe H., Müller K. 1987. Vergleichende Untersuchungen über semiquantitative und quantitative Methoden zur Bestimmung von Nitrat in Kartoffelknollen. Potato Research, 29, 333-344.

18. Lachman J., Hamouz K., Dvořak, P., Orsák M. 2005. The effect of selected factors on the content of protein and nitrates in potato tubers. Plant Soil and Environment, 51(10), 431-438.

19. Leszczyński W. 2012. Nutrition value of potato and potato products. Biuletyn IHAR, 266, 5-20.
20. Marks N. 2009. Content of nitrates, nitrites and heavy metals in potato tubers depending on their storage period duration. Inżynieria Rolnicza, 1, 183-187.

21. Mozolewski W., Smoczyński S. 2004. Effect of culinary processes on the content of nitrates and nitrites in potato. Pakistan Journal of Nutrition, 3, 357-361.

22. Pobereżny J. 2008. The content of nitrates (V) in potato tubers in depending on the cultivation site and storage conditions. Polish Journal of Nutrition Sciences, 23 336-346. doi 10.2478/v10020-008-0026-y.

23. Rembiałkowska E., Średnicka D. 2009. Organic food quality and impact on human health. Agronomy Research, 7 (Special issue II), 719-727.

24. Rogozińska I., Pawelzik E., Pobereżny J., Delgado E. 2005. The effect of different factors on the content of nitrate in some potato varieties. Potato Research, 48, 167-180. doi:10.1007/BF02742374·0.84.

25. Wegener Ch.B., Jansen G., Jürgens H.U., 2015. Bioactive compounds in potatoes: Accumulation under drought stress conditions. Functional Foods in Health and Disease, 5 (3), 108-116.

26. Wierzbicka A., 2011. Some quality characteristics of potato tubers grown in the ecological system depending on irrigation. Journal of Research and Applications in Agricultural, 56 (4), 203-207.

27.Zarzecka K., Gugała M., Mystkowska, I. 2010. Herbicide residues and nitrate concentration in tubers of table potatoes. Journal of Toxicology and Environmental Health, A, 73, 1244-1249. doi: 10.1080/15287394.2010.492011. 